\title{
SEASONAL INCIDENCE OF BREEDING, MOULT AND LOCAL DISPERSAL OF RED-BILLED FIREFINCHES LAGONOSTICTA SENEGALA IN ZAMBIA
}

\author{
Robert B. Payne
}

Received 12 January 1979

Tropical African birds, especially in the non-forested regions, are characteristically seasonal in their breeding and moult (Moreau 1950, Morel \& Morel 1962, Fry 1970, Benson et al. 1971, Sinclair 1978). Several species also are known to make seasonal movements, usually related to seasonal aspects of rainfall (Moreau 1966, Ward 1971, Elgood, Fry \& Dowsett 1973). Such migrations may be local or cover hundreds or thousands of kilometres (Elgood, Fry \& Dowsett 1973). Most studies of ringed populations have been localized, with the result that seasonal breeding and moult have been readily discernible but the nature of seasonal movements has been less clear (Morel 1973, Woodall 1975, Skead 1975, Greig-Smith 1978).

Red-billed Firefinches Lagonosticta senegala are usually considered sedentary and seasonal breeders. They have been studied most intensively in Senegal (Morel 1973). Although in most parts of their range they occur year round, in some they are seasonal in occurrence (Jones \& Ward 1977). During a study of the population structure and song dialects of the Village Indigobird Vidua chalybeata, the brood parasite of Red-billed Firefinches (Payne \& Payne 1977, Payne, in press), firefinches at Lochinvar National Park, Zambia, were trapped and ringed, and seasonal activity among them was monitored closely for 18 months and in less detail for another 2.5 years.

\section{STUDY AREA AND METHODS}

Lochinvar National Park lies along the southern bank of the Kafue River flood plains in Zambia, and extends several kilometres into open woodland. The central part of the study area was at $15^{\circ} 57^{\prime} \mathrm{S}, 27^{\circ} 15^{\prime} \mathrm{E}$. The habitat has been described elsewhere (Sheppe $8 x$ Osborne 1971, Sheppe 1975, Douthwaite \& Van Lavieren 1977, Payne \& Payne 1977). The climate is seasonal with rains falling from November to May, the rainiest months usually being January to March. The average annual rainfall is $830 \mathrm{~mm}$. Rainfall in the area of Lochinvar is highly seasonal though early or late rains may fail; available maximum and minimum rainfall figures show that the driest years on record have at least $40 \%$ of the mean annual rainfall (Sheppe \& Osborne 1971). Temperature is less seasonal, with average monthly temperatures ranging from $15.3^{\circ} \mathrm{C}$ in July to $25.2{ }^{\circ} \mathrm{C}$ in October (Sheppe \& Osborne 1971).

Red-billed Firefinches were found in open woodland, especially in Acacia nilotica woodlands, and along the brushy banks of seasonal streams and watercourses, and also were common in the woodlands, cultivated land and villages south and east of the park. Permanent sources of water available to birds in the woodlands were restricted to two natural hot springs (Bwanda and Gwisho), overflow from human water storage areas near the staff compounds at Chilundu and Mansangu (Fig. 1) and small waterholes associated with villages outside the park. Firefinches do not occur on the treeless flood plain, which is more than $20 \mathrm{~km}$ wide at the Lochinvar area. Thus the Kafue River and flood plain may be a local barrier to dispersal.

In total, 863 Red-billed Firefinches were caught by mist net from January 1972-July 1973. All were sexed and aged by plumage, ringed on the tarsi either with a unique combination of four colours, with a numbered coloured ring, with both or with a numbered National Museum of Zambia ring, and released at the site of capture. Netting and 
ringing continued less intensively in March, April and December 1974, and in May, June and December 1975. During the first 18 months and in 1974 ringed birds were recaptured (or, more rarely, sighted) on 518 instances.

Wing moult was scored by the number of the outermost growing primary, with scores from 0 (no moult) and 1 (innermost primary at all stages of growth from pinfeather to nearly fully grown but still. sheathed at base) to 9 (outermost large primary growing). Fat was scored by examining the bird through the thin skin, and recorded as 'no fat', 'little fat', or 'moderate fat' (McCabe 1943); no birds handled were 'fat' or 'very fat'. Some

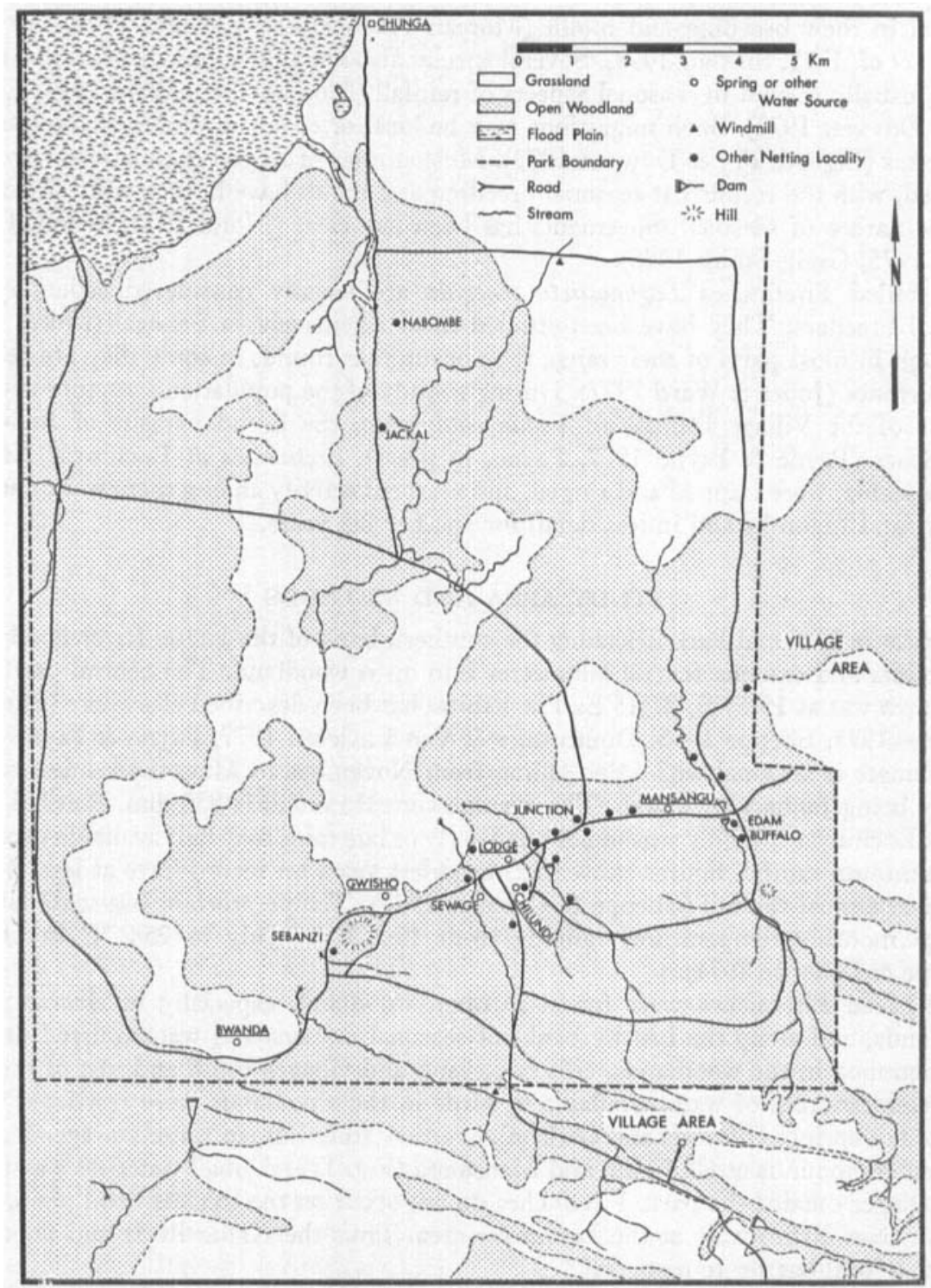

Figure 1. Map of Lochinvar National Park, Zambia, excluding the northern margin. The main netting localities are indicated by name, minor localities by filled circles. Permanent or nearlypermanent sources of water are underlined. Chunga lies at the northern edge of the flood plain near the confluence of the Nampongwe and Kafue Rivers. 
birds were weighed to $0.5 \mathrm{~g}$ with a $30 \mathrm{~g}$ Pesola field balance. Females were examined for presence and condition (Bailey 1952) of a brood patch; males had no brood patch.

The netting schedule was not systematic. As many as 19 nets were used per day in 31 sites at least $100 \mathrm{~m}$ apart, changing as waterholes attracted the birds or dried up, and from one part of the park to another. Thus, two net sites were used in at least 10 months of a calendar year, but none were used in all months, and some were used in only one month.

Population densities of firefinches were estimated by two techniques. First, D. Lewis walked each of two transects twice a month for a year (June 1972 to May 1973) between 0800 and $1000 \mathrm{~h}$ on days without wind, counting all birds seen or heard. The transects were $600 \mathrm{~m}$ long in open woodland between Chilundu and Sebanzi. The transect habitat was better-than-average habitat at Lochinvar for firefinches, with Acacia nilotica woodland and a permanent pool of water (sewage pond). Transects were repeated in 1975 by K. Payne who recorded radial distances and transect angles from observer to the bird for each encounter. These data allowed calculation of the lateral distance of each bird to the transect line, hence the effective width of the transect (Seber 1973, Emlen 1977). Secondly, a capture-recapture estimate of numbers was made of birds netted and ringed during January-March 1972 and recaptured in April 1972 in the same area within $1 \mathrm{~km}$ of Lodge site. This area included the transect area and was dominated by large patches of Acacia nilotica woodland. It also included the active centre (Junction site) of the Village Indigobird population studied in 1972 and 1973 (Payne \& Payne 1977). The population $(P)$ was estimated as $P=N . N^{\prime} / N^{*}$, where $N$ is the number of birds ringed in the first period, $N^{\prime}$ the number of birds caught in the second period and $N^{\prime \prime}$ the number of birds taken in the second period that were ringed in the first.

\section{RESULTS}

LOCAL BREEDING SEASON

Red-billed Firefinch nests are domed structures concealed in cavities, recesses, under overhangs or in leafy bushes. Only two nests were found in the park. Outside the park, where the firefinches nested on the underside of thatched roofs in villages, 45 nests with eggs or nestlings were found between 24 February and 14 May in 1972 and 1973. A check of more than 40 village houses in late May and early June in 1973 found no active nests, suggesting a decline in breeding activity, but D. Lewis found one late nest with two fresh eggs in a village on 19 August 1972. The nest contents have been described elsewhere (Payne 1977).

Palpable eggs were found in netted females in every two-week period from late April to early July in 1973; no intensive effort was made before that time to palpate eggs. Conditions of brood patches also indicated a prolonged nesting season, from February to August (Table 1). The female handled in September with a wrinkled brood patch had not begun to moult and may have been attending young. Nearly all females examined from March to September had a brood patch, thus all, or nearly all, females in the population appear to have nested. Morel (1973) found that both males and females in Senegal breed in their first year of life. The brood patch data indicate that the birds at Lochinvar generally did so.

Juveniles were first seen when netted on 18 March 1973, and the first juveniles in moult were netted in April. The latest juveniles not yet beginning the post-juvenal moult were netted in late October. These dates are again consistent with nestings from February to August or perhaps September. The proportion of young in the monthly netting samples rose from March to April and remained high, with young outnumbering adults in August and September (Fig. 2). The plateau through the breeding season may in part reflect mortality among young birds, but the drop after September is largely attributable to the impossibility of distinguishing moulted young from adults. 


\section{TABLE 1}

Condition of the brood patch among adult female Red-billed Firefinches examined in or near Lochinvar National Park. Numbers in the body of the table combine all adult females handled, from 1972 to 1975, for which brood patch condition was noted

\begin{tabular}{|c|c|c|c|c|c|c|c|c|c|c|c|c|}
\hline \multirow{2}{*}{$\begin{array}{l}\text { Condition of } \\
\text { brood patch }\end{array}$} & \multicolumn{12}{|c|}{ Calendar month } \\
\hline & $\mathrm{J}$ & $F$ & $\mathbf{M}$ & $\mathbf{A}$ & $\mathbf{M}$ & $\mathrm{J}$ & $\mathrm{J}$ & $\mathbf{A}$ & s & 0 & $\mathbf{N}$ & $\bar{D}$ \\
\hline $\begin{array}{l}\text { None } \\
\text { Deferthered } \\
\text { Vascular } \\
\text { Oedematous } \\
\text { Wrinkled } \\
\text { Total examined }\end{array}$ & 2 & $\begin{array}{r}4 \\
14 \\
1\end{array}$ & $\begin{array}{r}8 \\
6 \\
14\end{array}$ & $\begin{array}{r}6 \\
11 \\
25 \\
42\end{array}$ & $\begin{array}{r}1 \\
20 \\
65 \\
8 \\
94\end{array}$ & $\begin{array}{r}1 \\
1 \\
2 \\
46 \\
8 \\
58\end{array}$ & $\begin{array}{r}2 \\
4 \\
31 \\
10 \\
47\end{array}$ & $\begin{array}{l}5 \\
1 \\
6\end{array}$ & $\begin{array}{l}1 \\
1\end{array}$ & 4 & 3 & 6 \\
\hline
\end{tabular}

Note: ${ }^{1}$ Deacriptions after Bailey (1952). Birds with brood patches described as intermediate were allocated to the more advanced condition. The high proportion of females with 'oedematous' brood patches in June, July and August is questionable; many of these probably were females with inactive or wrinkled brood patches, but all at least had evidently nested in the current breeding season.

\section{TABLB 2}

Ages of birds netted from May to fuly in three successive years. See text for comment

\begin{tabular}{lcccc}
\hline Year & $\begin{array}{c}\text { Seasonal } \\
\text { rainfall (mm) }\end{array}$ & $\begin{array}{c}\text { Number of } \\
\text { adults }\end{array}$ & $\begin{array}{c}\text { Number of } \\
\text { juveniles }\end{array}$ & $\begin{array}{c}\text { Juveniles as } \\
\% \text { total netted }\end{array}$ \\
\hline 1972 & 785 & 289 & 124 & 30 \\
1973 & $602^{2}$ & 215 & 102 & 32 \\
1974 & 867 & 36 & 30 & 45 \\
\hline
\end{tabular}

Note: ${ }^{1}$ Early rain were normal but March, April and May were exceptionally dry (0.8 mm).

The proportion of young birds netted in May, June and July in 1972, a year of average rainfall, was very similar to the proportion in the same months in 1973 , a drier year, (Table 2, $x^{2}=0.323, P<0.8$ ). In 1974 birds were netted mainly in July, and this may explain the higher proportion of juveniles recorded in that year. The level of recruitment of firefinch young into the population appears similar from year-to-year.

MOULT

No birds were in moult in January and February. A few males and females had begun head- or body-moult by March or April, but most did not moult until a month or two into the dry season. Males appeared to begin body-moult earlier than females; $50 \%$ of the male sample was in moult half a month earlier than the females (Fig. 3). However, detailed descriptions of males early in the moulting season showed that few feathers were growing.

Juveniles began to replace the juvenile body plumage shortly after they first appeared in the net samples. The first feathers to be replaced were the lores, buff in the juvenile and red in the adults of both sexes. By early April more than half the juveniles were moulting. 


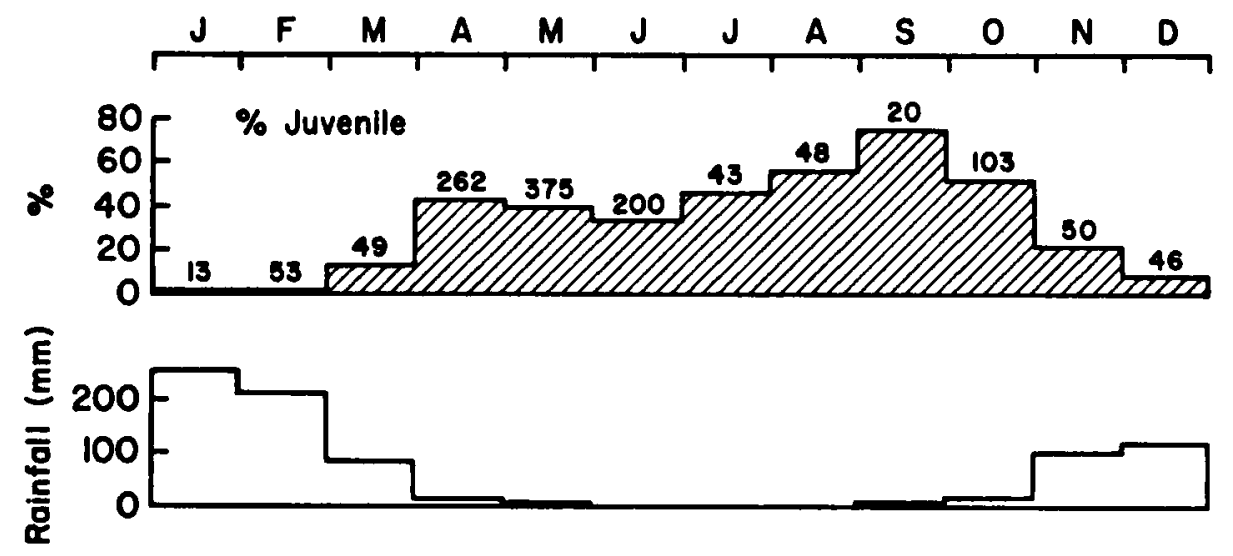

Figurs 2. Seasonal changes in proportion of juvenile Red-billed Firefinches in and near Lochinvar National Park. Numbers indicate the total number of firefinches netted in the monthly samples cumulatively from 1972 to 1974. Rainfall figures are monthly averages for the three years of the study (1971-1972 rainy season through 1973-1974 rainy season).

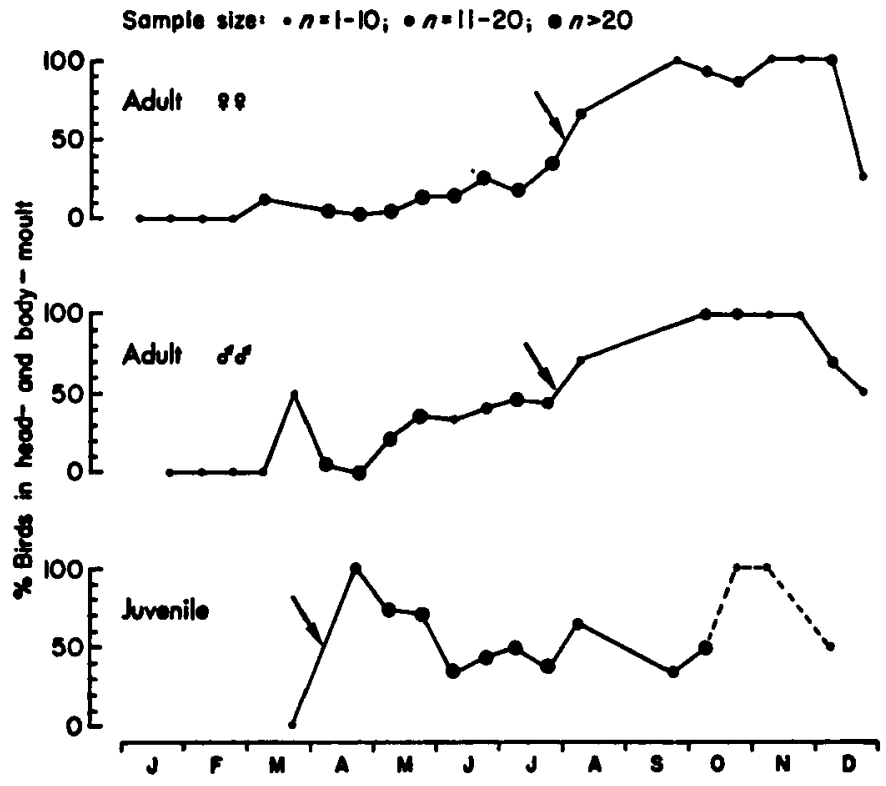

FIGURE 3. Incidence of body-moult in Red-billed Firefinches at Lochinvar National Park, 19721974. The arrow indicates the time by which moult had been initiated in $50 \%$ of the sample. Sample sizes are shown by the size of the symbols.

Some adults had begun wing-moult as early as May; moulting males outnumbered moulting females in this month $\left(\chi^{2}=5.51\right.$, d.f. $\left.=1, P<0.01\right)$. Flight feathers were replaced gradually with more than $90 \%$ of the birds having only a single primary growing at any time. Juveniles that began body-moult in March and April did not moult the primaries at that time. Wing-moult was seen in juveniles as early as late May, but in most did not begin until July or August. Wing-moult was completed in a few birds by October, but in most not until December. In four previously ringed young birds primary moult continued into December, after the juvenile body plumage had been completely replaced. These firefinches took about four months to complete the wing-moult, i.e., the 
period between the times when $50 \%$ of the population began and completed the moult, cf. 3.5 months reported by Morel $(1973: 31)$ in Senegal and 3-4 months in northern Nigeria (Fry 1970).

The moult of individual firefinches resembled that of the population as a whole (Fig. 4). An adult male was caught on 28 August unmoulted and again on 14 December in entirely fresh plumage; his moult, therefore, was completed in less than 114 days. Late-season birds may moult more rapidly than earlier birds, as suggested by November and December dates for the only two birds in the sample that had more than two simultaneously growing
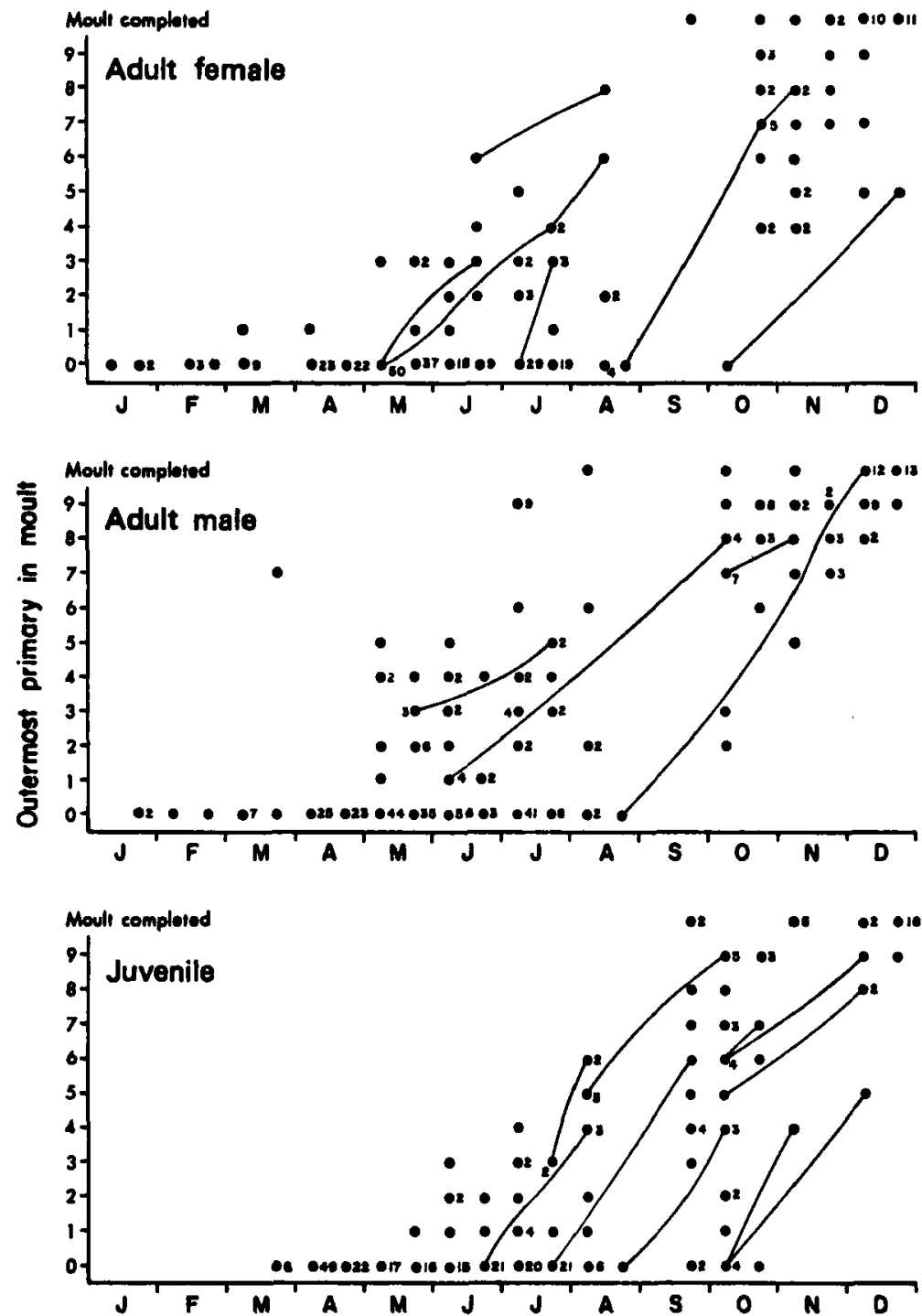

Figure 4. Incidence of primary moult in Red-billed Firefinches at Lochinvar National Park, 19721974. Numbers indicate the sample size for each dot; a dot without a number represents one bird. Lines connect the moult condition for individual birds recaptured during one moulting season when at least 15 days elapsed between captures. Most young birds were indistinguishable from adults after September. Those included had retained some juvenile feathers or had been ringed as juveniles earlier in the season. 
primaries. The most rapid moult recorded was shown by an adult female not in moult on 26 August, later taken with new inner primaries grown and primaries 6 and 7 growing on 8 October. At this rate the female would moult in less than 2.5 months. Overall, however, no difference in moult is evident between sexes or adults and young.

No females were growing feathers if they had a vascular or oedematous brood patch, and none refeathered the brood patch before beginning a widespread moult of the head and body. Apparently individual birds do not moult and breed at the same time and birds may postpone moult if they breed late in the season.

Although firefinches moult for 3.5-4 months in the field, under certain conditions they moult much more rapidly. Four captives (from Rhodesia but morphologically indistinguishable from Lochinvar birds) kept in controlled environment chambers for three years with a light cycle $12 \mathrm{~L} / 12 \mathrm{D}$, temperature $27^{\circ} \mathrm{C} \pm 1{ }^{\circ} \mathrm{C}$, and $70 \%$ relative humidity, always completed the body- and wing-moult in $\mathbf{4 0}$ days or less. The captives often had three or four primaries growing at a time. The contrast between these captives and wild birds suggests an individual adaptability of moult schedule to local conditions. A protracted moult may allow birds to arrest the moult and breed at short notice, for instance after heavy rain in the normal dry season. Firefinches display and breed when only a few months old, even when still partly in juvenile plumage (Morel 1973, Payne 1973, 1976). Thus the protracted moult of juveniles may have the same adaptive basis as that of the adults. At Lochinvar, however, we found no evidence of out-of-season breeding or of interrupted or arrested moult.

FOOD

The food of netted birds was sampled by inserting a flexible plastic tube through the mouth into the crop, then withdrawing the plunger of a small syringe attached to the tube. Nearly all foods sampled were grass seeds of 1-2 mm, and most were identified as Echinochloa colonum or Setaria spp. (Table 3). These were among the most abundant local grasses and their representation in the diet may reflect in part their availability.

\section{TABle 3}

Frequency of occurrence of grass seeds in crop samples of Red-billed Firefinches

No. of
birds
Month sampled Echinochloa' Setaria Urochloa Panicum Chloris Digitaria Eleusine Unidentified

\begin{tabular}{|c|c|c|c|c|c|c|c|c|}
\hline $\begin{array}{l}\mathbf{J} \\
\mathbf{F} \\
\mathbf{M} \\
\mathbf{A} \\
\mathbf{M} \\
\mathbf{J} \\
\mathbf{J} \\
\mathbf{A} \\
\mathbf{S} \\
\mathbf{O} \\
\mathbf{N} \\
\mathbf{D}\end{array}$ & $\begin{array}{r}0 \\
4 \\
0 \\
17 \\
26 \\
2 \\
4 \\
14 \\
0 \\
25 \\
6 \\
13\end{array}$ & $\begin{array}{r}2 \\
15 \\
23 \\
2 \\
4 \\
8\end{array}$ & $\begin{array}{r}2 \\
6 \\
13 \\
2 \\
4 \\
14 \\
6 \\
6\end{array}$ & $\begin{array}{r}3 \\
10\end{array}$ & $\begin{array}{l}1 \\
1\end{array}$ & 2 & 1 & 2 \\
\hline
\end{tabular}

Note: ${ }^{1}$ Grass seeds were identified in most cases only to genus, and for several genera more than one species occurs at Lochinvar. Local representatives of these genera identified in woodland habitats at Lochinvar are $E$. colonum, $E$. holubii, $S$. anceps, $S$. ciliolata, $S$. homonya, $S$. pallidefusca, S. sphacelata, S. torta, U. mosambicensis, (Panicum spp.), C. gayana, C. virgata, $D$. comifera, D. gazensis, D. milanjiana, D. setivalva, D. ternata and $E$. africana (Douthwaite \& Van Lavieren 1977). 
These grasses are seasonal; the Setaria species in question produce only one crop of seeds in a year, but the Echinochloa has several generations in a single rainy season. Fallen seeds become less abundant later in the dry season. In monthly counts of grass seeds on the ground at Lochinvar, D. Lewis found a seasonal cycle of abundance with the number of seeds per $\mathrm{m}^{2}$ late in the dry season decreasing to $10 \%$ of the number late in the rains. Seeds were locally depleted where large flocks of Red-billed Quelea Quelea quelea fed in the dry season and were also removed by Pheidole sp. ants. When the grass cover was burned in the dry season the seeds became more visible and perhaps more available to the birds. Evidently the birds were able to find the same kinds of seeds from the end of the rains through succeeding months after the grasses had fruited.

The nestling diet consisted mostly of small grass seeds. Examination of the crop contents through the translucent skin of small nestlings showed at least $90 \%$ seeds. A few insects were also included, notably small ground-dwelling termites Odontotermes sp. Red-billed Firefinches in captivity in my aviaries have reared young on a diet of small seeds supplemented occasionally with insects. It seems unlikely that seasonal change in insect abundance has much influence on the annual cycle of this bird. Perhaps a shortage of seeds at the end of the year, when the unconsumed remainder has germinated but the new grasses have not yet seeded, influences the onset of the breeding season.

\section{ESTIMATES OF POPULATION DENSITY}

Colour-ringed birds moved several hundred metres within a breeding season and did not restrict their movements or their singing to the area by their nest site. In one month 41 adults were taken in one net, demonstrating the overlapping ranges of activity of individuals in the breeding season. Near Gwisho hot springs, 108 adult and juvenile firefinches were netted in May 1972. In this sample, 16 birds had been ringed earlier: one trapped at Gwisho, eight within $0.5-1.0 \mathrm{~km}$ and seven at $1-2 \mathrm{~km}$ distant. On this date, the number of ringed firefinches originally taken within $1 \mathrm{~km}$ of Gwisho was 30 ( 9 recaptures), 98 birds had been ringed $1.2 \mathrm{~km}$ away (7 recaptures), and $333-6 \mathrm{~km}$ distant ( 0 recaptures). The indicated movements within this short period were thus no greater than $2 \mathrm{~km}$ and most were shorter.

\section{TABLE 4}

\section{Monthly average counts of Red-billed Firefinches along a $600 \mathrm{~m}$ transect $^{1}$}

\begin{tabular}{|c|c|c|c|c|c|c|c|c|c|c|c|c|c|}
\hline \multirow[b]{2}{*}{$\begin{array}{l}\text { Month } \\
\text { Total birds }\end{array}$} & \multicolumn{7}{|c|}{1972} & \multicolumn{6}{|c|}{1973} \\
\hline & $\underset{5 \cdot 5}{J}$ & $\underset{12 \cdot 3}{J}$ & $\underset{6 \cdot 2}{A}$ & $\begin{array}{c}S \\
6 \cdot 7\end{array}$ & $\underset{10.2}{O}$ & $\underset{11 \cdot 0}{N}$ & $\underset{2 \cdot 5}{D}$ & $\begin{array}{l}\mathrm{J} \\
0\end{array}$ & $\underset{1 \cdot 0}{F}$ & $\begin{array}{l}M \\
2 \cdot 0\end{array}$ & $\underset{1.8}{A}$ & $\underset{4 \cdot 0}{M}$ & $\mathrm{~J}_{5 \cdot 0}^{\mathrm{J}}$ \\
\hline
\end{tabular}

Note: ${ }^{1}$ Figures are monthly averages of four transect samples in each case.

Excluding recaptures, 92 adults were netted and ringed during February-April 1972 in the area between Gwisho, Lodge and Junction. In May, of 121 adults netted in this area, 13 had previously been ringed. The estimated population of the area (see Methods) is 856 birds. The source area is not well defined but, from the extent of suitable habitat seen on aerial photographs and vegetation maps, was about $10 \mathrm{~km}^{2}$, indicating a density of $c .86$ birds per $\mathrm{km}^{2}$, i.e., $40-45$ breeding pairs per $\mathrm{km}^{2}$.

Counts of birds heard or seen along the transect in 1972 and 1973 ranged from 0 to 11 birds. January was the only month in which no birds were noted, although their presence was demonstrated by netting captures off the transect area. Larger numbers late in the dry season included independent young and birds which had bred elsewhere which 
moved to the local sewage pond for water. The overall average was 5.27 birds per transect, the average for March-June was 3.33 (Table 4). Most birds were detected between 10 and $20 \mathrm{~m}$ from the observer (Fig. 5). Usually they flushed though a few remained in bush or grass until the observer approached within $10 \mathrm{~m}$. The effective detection distance of Red-billed Firefinches was about $50 \mathrm{~m}$ on each side of the transect. The transect thus corresponds to a $100 \mathrm{~m}$ width. On this basis, the indicated average density in 1973 was 33 birds per $\mathrm{km}^{2}$. The 1975 transect samples ranged from 2 to 6 and averaged 3.5 birds, equivalent to 5.83 birds per transect $\mathrm{km}$, or 58 birds per $\mathrm{km}^{2}$, somewhat lower than the capture-recapture estimate. Yet these figures are of the same order of magnitude, and both indicate a population of at least several hundred birds in Lochinvar.

SEASONAL MOVEMENTS, LOCAL DISPERSAL AND POPULATION STRUCTURE

Red-billed Firefinches were seen and netted in all months at Lochinvar. Ringed birds caught during any one month were likely to have been netted originally in nearly any month of the year (Fig. 6). Little netting was done in January, September and November, and the empty cells for these months reflect the low netting effort. Ringed birds caught in the breeding season had originally been taken at Lochinvar in all months except September,

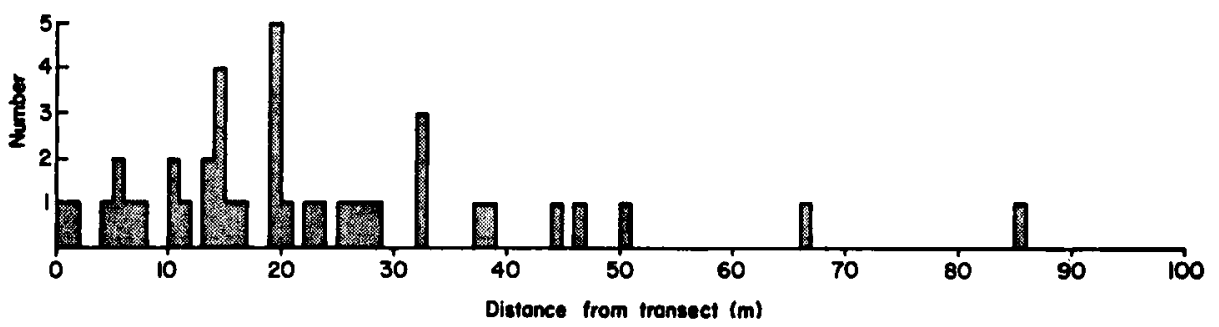

Figure 5. Distance from firefinch to transect line in April and May 1975. Distances are perpendiculars calculated from the distance from observer to bird upon detection and the angle of the bird-observer-transect line. Note the modal distance $(20 \mathrm{~m})$ and the near-absence of observations further than $50 \mathrm{~m}$.

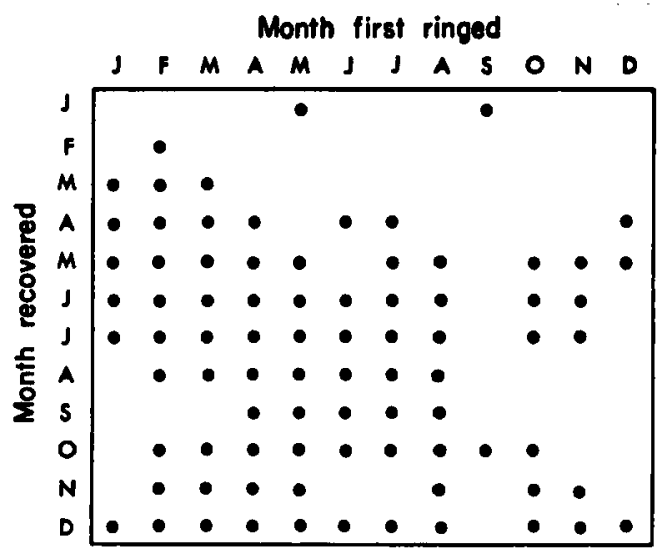

FIgURE 6. Seasonal pattern of recaptures of Red-billed Firefinches at Lochinvar National Park. A month in which at least one firefinch was recaptured in the row and earlier had been captured in the column is indicated with a dot. Most netting and ringing was done in the first calendar year, and little or no netting was carried out in several months of the second year. Cells below the diagonal indicate a subsequent capture of birds first ringed in 1972. Only four birds were netted from January through April in 1973, hence the few recoveries in that period for birds ringed in the previous year. Few birds were netted or ringed in January, September and November in the first year, and the low netting effort explains the apparent gaps in the rows and columns for those months (few birds ringed and few birds sampled to obtain recoveries). The figure includes all birds controlled through December 1974. 
and the ringed birds captured in September had been taken in the park in the breeding season. Most netting was carried out in the first year, hence the lower diagonal of Figure 6 should be the more complete. Of the 66 cells below the diagonal, all but eight are filled, and one (January-September) is represented in the corresponding cell above the diagonal. Some ringed birds remained at the same locality within the park in all seasons (Fig. 7), and two were always recaptured within a $1 \mathrm{~km}$ radius. Of 26 birds caught four times or more, 12 were caught in the park in both wet and dry seasons. There is thus no indication of seasonal absence or general, large scale movement by the population.

The seasonal changes in numbers indicated in Table 4 can be explained by recruitment of young, seasonal difference in activity and local movement within the park, rather than by long-distance migration. Our data on body weight and fat indicated no seasonal changes in body composition as would be expected in migrants. Year-round sightings and the seasonal pattern of captures and recaptures both indicate that these firefinches are sedentary with most local birds remaining in the park in all seasons.

Yet some Red-billed Firefinches made movements of several kilometres. We obtained 46 records of dispersal greater than $5 \mathrm{~km}$. Seasonal movements were sometimes repeated from one year to the next. For instance, one bird was netted in two successive dry seasons at water $3 \mathrm{~km}$ from the site where he was netted in the breeding season. Two adults and

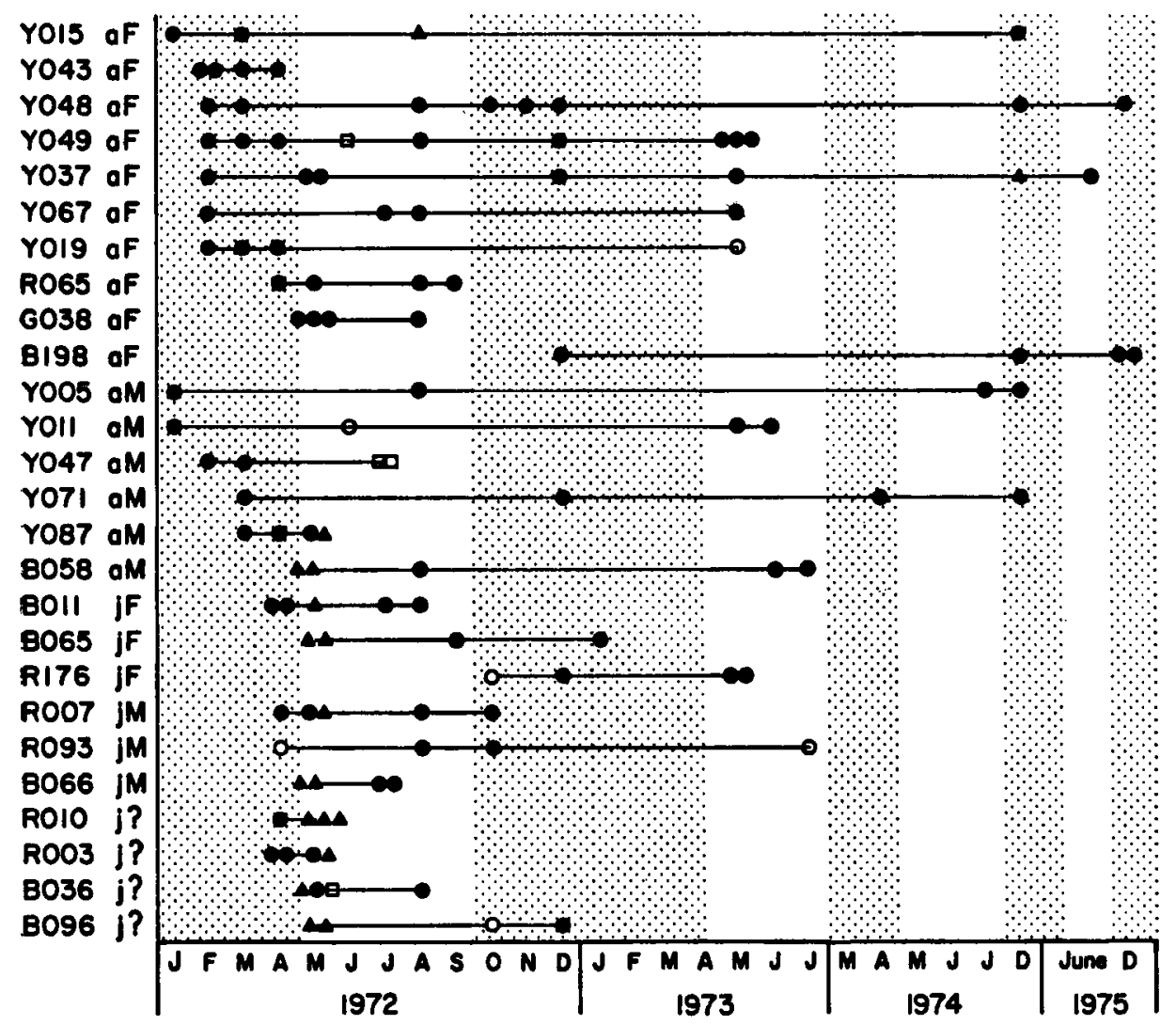

Figure 7. Dispersal histories of all Red-billed Firefinches captured at least four times at Lochinvar National Park, Zambia. Letters and numbers on the left indicate individual identity, age $(\mathrm{j}=$ juvenile, $\mathrm{a}=$ adult), and $\operatorname{sex}(\mathrm{M}=\mathrm{male}, \mathrm{F}=$ female, ? = unknown). Symbols indicate the four main netting areas: $O$, Junction area; $\Delta, G$ wisho area; $O$, MansanguBuffalo; $\square$, Jackal or Nabombe. 
a juvenile were netted in the wet season or early dry season in 1972 and 1973 at Junction site, but in the intervening dry season they were at the Mansangu waterhole $5 \mathrm{~km}$ distant. Several birds ringed in the breeding season near Junction later were caught in the dry season at Mansangu, and others ringed at Mansangu were caught in the next breeding season near Junction.

Other birds moved longer distances. Two juveniles and an adult male netted at Sewage waterhole in May-July 1972 later were caught at Jackal or Nabombe, 10.4 and $12.3 \mathrm{~km}$ north, near the southern edge of the flood plain. One of these young birds was recaptured back at Sewage in August, three weeks after Nabombe was nearly dry and Jackal had been dry for several weeks.

\section{TABLE 5}

Dispersal distances of Red-billed Firefinches ringed in one breeding season (i.e., February-fune) and recaptured in a subsequent breeding season

\begin{tabular}{|c|c|c|c|c|c|c|c|c|c|c|c|c|c|c|c|}
\hline \multirow[b]{2}{*}{ Age } & \multicolumn{14}{|c|}{ Dispersal distance $(\mathrm{km})$} & \multirow{2}{*}{ Totals } \\
\hline & $\overparen{0.0}$ & 0.1 & 0.3 & 0.4 & 0.5 & $1 \cdot 1$ & 1.4 & 1.5 & 1.6 & $2 \cdot 4$ & $2 \cdot 6$ & $5 \cdot 4$ & $5 \cdot 6$ & 6.8 & \\
\hline $\begin{array}{l}\text { Adult' }{ }^{1} \\
\text { Juvenile }\end{array}$ & $\begin{array}{r}10 \\
2\end{array}$ & $\begin{array}{l}1 \\
1\end{array}$ & 1 & 1 & 1 & $\begin{array}{l}4 \\
1\end{array}$ & 1 & 2 & 5 & 1 & $\begin{array}{l}1 \\
1\end{array}$ & 2 & 2 & 1 & $\begin{array}{l}28 \\
10\end{array}$ \\
\hline
\end{tabular}

Note: ${ }^{1}$ All females had active brood patches and, on this evidence, were breeding.

The movements lacked strong directionality. Some birds shifted north several kilometres, to the edge of the Kafue flood plains, in the dry season. At the same time, other birds moved from Gwisho, Sewage and Junction, eastward to Mansangu, others caught 2-3 km east of Mansangu were recaptured westward at Gwisho and Sewage, having passed over Mansangu, where water was intermittently available.

Records of birds captured twice within 90 days suggest seasonal dispersal late in the rainy season or soon after the rains, and then again late in the dry season (Fig. 7). The most rapid movement detected was for a juvenile netted at Gwisho on 2 May, at Sewage on 16 May, and $10.4 \mathrm{~km}$ north at Jackal on 26 May in 1972. This bird and several others dispersed from a site where water and seed were still available; firefinches were seen at Sewage in all months.

The timing of movement of birds into breeding areas from their dry season areas was not closely synchronized. Female Y049, at Junction in February, March and April, then at Nabombe in June 1972, was netted again at Sewage in August and stayed in the woodland area through the next breeding season. Other birds moved from Sewage to Nabombe after this bird made the reverse movement. The length of time that birds spent in the dry season near the waterholes varied and some were recaptured at Nabombe repeatedly during July and August until the site dried and the grass burned. At Chunga, on the southern edge of the flood plains, Red-billed Firefinches were abundant in the dry season but scarce in March and April, though a few nested. In October and November 1972, 39 were netted and ringed at Chunga. Three birds reappeared at Junction in May or June the next year, at a time when some other birds left their breeding areas. The variation in timing suggests that some birds remained at dry season water until the rainy season, then returned to their breeding areas, but others were more mobile between breeding seasons.

Dispersal with the early rains is also suggested by the timing of recovery of birds ringed at Lochinvar and killed in the villages of Kemba and Banakaila. All ringed Lochinvar 
birds killed by small boys in the villages were taken when the rains had just started. Two adults netted at Junction and Gwisho were taken $12 \mathrm{~km}$ southeast at Kemba in December 1973. The other three were adults first ringed the same year or in the previous year during May and June and taken in December 1974 at Banakaila, 8-14 km from their ringing site. The villages have surface water which may attract firefinches in the dry season.

Dispersal is genetically effective only when birds undergo a net movement from birthplace to breeding site or between breeding seasons. Local migrants, such as Y049 which returned to the same breeding grounds in successive years or a juvenile (R093) which dispersed and then returned to the area where it was born, undergo no net dispersal. In the main, these Red-billed Firefinches were locally effective dispersers (Table 5). Nearly half the adults were recaptured at the same site or nearby in successive breeding seasons, whereas 7 of 10 birds ringed as juveniles were recaptured at distances exceeding $300 \mathrm{~m}$. Average dispersal distance of adults was $1.8 \mathrm{~km}$, of juveniles, $2.3 \mathrm{~km}$. Because netting was concentrated within an area $2 \mathrm{~km}$ in diameter, the estimate of average dispersal distance is a minimum. The tendency for young birds to disperse further than adults was significant (Mann-Whitney test, $U=179, P<0.05$ ). The observed dispersal between breeding seasons indicates that there are no local, genetically isolated populations of Red-billed Firefinches around Lochinvar.

\section{DISCUSSION}

The seasonality of open woodlands in southern central Africa imposes a pronounced seasonality on the local birds. Seasonal breeding, moulting and local dispersal between the breeding area and dry-season sites with permanent water all are adaptations of the local firefinches that adjust their schedules of activity to the seasonal habitat changes. The birds have breeding seasons which are more sharply set off in time from moulting seasons, in contrast to birds of tropical forests (Snow \& Snow 1964, Fogden 1972, Diamond 1974, Foster 1974), and in contrast to many species in the drier parts of Australia where rainfall is less predictable (Immelmann 1970, Immelmann \& Immelmann 1967).

Seasonal habitat changes that are important for timing of the breeding season include the increased abundance of grass seeds after early rains and also perhaps increased availability of nesting sites and material. Small streams and rain pools may also be necessary for successful nesting in parts of the park not near a permanent source of water. Apart from these seasonal factors, grass seeds, nesting materials such as feathers of wild or domestic fowl, and some nesting sites are available throughout the year.

The protracted moult of 3.5-4 months differs from that of most small birds in northern temperate latitudes. Moult is even more drawn out in time, and presumably draws fewer resources from the bird, in tropical forest regions (Snow \& Snow 1964, Payne 1971, Fogden 1972, Foster 1974). The slow moult may allow the firefinches to breed with unseasonal rainfall. Museum specimen labels shows seasonal change in testis size, with males in breeding condition having testes $5-6 \mathrm{~mm}$ in length and moulting males with testes only $2-3 \mathrm{~mm}$ in length. The seasonal change in testis size is less than in songbirds of northern temperate regions. Although it is questionable whether moulting males are reproductively competent and producing sperm, they might respond within a week or two to appropriate environmental change.

Although Red-billed Firefinches may move locally at Lochinvar and their seasonal abundance varies at some sites within the park, overall they are sedentary within the park area. In Senegal, Morel (1973) likewise found locally ringed birds around the year. In contrast, Jones \& Ward (1977) reported a local, seasonal disappearance of most Redbilled Firefinches at Molai, NE Nigeria, and found lower lipid levels among samples in the late dry season than in the early rains, shortly before the birds disappeared. They suggested that the lipids are premigratory fat deposits and that the birds may move northwards to breed; no evidence was obtained from ringing on the direction or distance 
of movement. Elsewhere in Nigeria, at Zaria the species has been considered a sedentary year-round resident (Fry 1970), and Elgood, Fry \& Dowsett (1973) did not consider it a seasonal migrant. Seasonal weight changes are not known in other semi-arid regions of west Africa (Davidson, Greig-Smith \& Fisher 1978).

The proximate factors involved in the timing of the seasonal activity in Red-billed Firefinches are not known. Lochinvar undergoes a seasonal difference in daylight of about $1.5 \mathrm{~h}$ from December to June and the birds may time their cycles by a photoperiodic response. An internal annual rhythm may also be involved: four Red-billed Firefinches that I kept in constant $12 \mathrm{~L} / 12 \mathrm{D}$ periods moulted at the same time \pm 2 months for three consecutive years. Short days do not seem to inhibit reproductive activity: my captive females have often laid during February at latitude $42^{\circ} \mathrm{N}$ in Michigan while on local daylight regime. The constancy in timing of the onset of moult and appearance of young in years of different rainfall at Lochinvar indicate some proximate independence of rainfall. In Senegal, Morel (1973) also found the same seasonality in years of different rainfall.

The information obtained on the dispersal of birds from their birth locality and on shifts of breeding site indicates that Red-billed Firefinches in the woodland around Lochinvar park form a single large breeding population of at least hundreds of birds. No local subpopulations are evident that would be free of immigration for more than a few generations. The comparatively high numbers present provide the opportunity to avoid inbreeding. The pattern of dispersal also indicates that Red-billed Firefinches do not live in locally differentiated populations that might correspond to the song dialect populations of their brood parasites, the Village Indigobirds (Payne \& Payne 1977). Several firefinches dispersed across an indigobird song boundary, and there were no locally isolated populations of the host species to explain the song dialect populations of the brood parasite.

I thank Dale M. Lewis for netting and ringing most of the firefinches and for comments on seasonal habitat changes. Tim Osborne and Karen Payne also netted and handled firefinches, and Billie Chipeta and Jali Makawa added their help. E. B. Nicolls of the Rhodesian Government Seed Testing Laboratory, Salisbury, identified grass seeds. M. P. S. Irwin allowed me to examine specimens in the National Museum of Rhodesia. I thank the National Parks and Wildlife Service for permitting the study of birds at Lochinvar National Park and for providing living space. The study was supported by grants from the National Science Foundation, U.S.A.

\section{SUMMARY}

Red-billed Firefinches were netted and ringed in Lochinvar National Park, Zambia, in 1972 and 1973 and were netted sporadically through 1975. Most nested from March to May, i.e., in the late rainy season and in the early dry season, though some nested as late as August. Nearly all evidently bred in their first year. Moult generally began after breeding was completed, and the indicated average duration of moult was 3.5-4 months. The main foods taken at all times of year were seeds of the seasonal grasses Echinochloa colonum and Setaria spp.

Local population densities, estimated by two methods, were in the range 33-86 birds per $\mathrm{km}^{2}$. Ringing results demonstrated overlapping activity ranges in the breeding season. Dispersal movements were non-directional, and varied up to $14 \mathrm{~km}$. Some ringed birds moved regularly each year between a particular waterhole and a breeding site; other did not move from the site of original ringing. Most dispersal was evident in the dry season (June and July) and in the early rains (October and November). Genetically effective dispersal of young from the site of birth to the site of the first breeding season was up to $6.8 \mathrm{~km}$, and some adults were netted in sites a few kilometres apart in successive breeding seasons. Some dispersing firefinches crossed the song dialect boundaries of the Village Indigobirds.

\section{REFERENCES}

BAILEY, R. E. 1952. The incubation patch of passerine birds. Condor 54: 121-136.

Benson, C. W., Brooke, R. K., Dowsett, R. J. \& Irwin, M. P. S. 1971. The birds of Zambia. London: Collins.

Davidson, N. C., Greig-Smith, P. W. \& Fisher, P. 1978. Weight changes of some savanna finches in Ghana. Bull. Nigerian Ornithol. Soc. 14: 73-79.

Diamond, A. W. 1974. Annual cycles in Jamacian forest birds. J. Zool., Lond. 173: 277-301.

Dolthwaite, R. J. \& VAN LAviEREN, L. 1977. A description of the vegetation of Lochinvar National Park, Zambia. National Council for Scientific Research, Tech. Rept. 34. Lusaka, Zambia. 
Elcood, J. H., FRY, C. H. \& DowszTT, R. J. 1973. African migrants in Nigeria. Ibis 108: 84-116. EMLEN, J. T. 1977. Estimating breeding season bird densities from transect counts. Auk $94: 455-468$. FOCDRN, M. P. L. 1972. The seasonality and population dynamics of equatorial forest birds in Sarawak. Ibis. 114: 307-343.

FostaR, M. S. 1974. A model to explain molt-breeding overlap and clutch size in some tropical birds. Evolution 28: 182-190.

Fry, C. H. 1970. Migration, moult and weights of birds in northern Guinea savanna in Nigeria and Ghana. Ostrich Suppl. 8: 239-264.

Greig-Smith, P. W. 1978. Migration of savanna birds revealed by local records. Bull. Nigerian Ornithol. Soc. 14: 89-92.

IMMELMANN, K. 1970. Environmental factore controlling reproduction in African and Australian birds-a comparison. Ostrich Suppl. 8: 239-264.

IMMELMANN, K. \& IMMRLMANN, G. 1967. Verhaltensökologische Studien an afrikanischen und australischen Estrildiden. Zool. Jahrb. Syst. Bd. 94: 609-686.

JONES, P. J. \& WARD, P. 1977. Evidence of pre-migratory fattening in three tropical granivorous birds. Ibis 119: 200-203.

McCabe, T. T. 1943. An aspect of collector's technique. Auk 60: 550-558.

Morst, M.-Y. 1973. Contribution à l'etude dynamique de la population de Lagonosticta sentegala L. (Estrildidés) à Richard-Toll (Sénégal). Mem. Mus. Nat. d'Hist. Nat., Paris, Sér. A, Zool. 78: 1-156.

Morki, G. \& Morke, M.-Y. 1962. La reproduction des oiseaux dans une région semi-aride: La Vallée du Sénégal. Alauda 30: 161-203, 241-269.

Morkau, R. E. 1950. The breeding seasons of African birds, 1. Land birds. Ibis 92: 223-267.

Moreau, R. E. 1966. The bird faunas of Africa and its islands. London: Academic Press.

Payne, R. B. 1971. Mechanisms and control of molt. In Farner, D. S. \& King, J. R. (eds.), Avian biology, 2. London: Academic Press.

Payne, R. B. 1973. Behavior, mimetic songs and song dialects, and species relationships of the parasitic indigobirds ( $V i d u a$ ) of Africa. Ornithol. Monogr. 11.

PAYNE, R. B. 1976. Song mimicry and species relationships among the West African pale-winged indigobirds. Auk 93: 25-38.

PAYNB, R. B. 1977. Clutch size, egg size, and the consequences of single $v$ multiple parasitism in parasitic finches. Ecology 58:500-513.

PAYNE, R. B. in press. Population structure and social behavior: models for testing the ecological significance of song dialects in birds. In Alexander, R. D. \& Tinkle, D. W. (eds.), Natural selection and social behavior: recent research and new theory. Portland, Oregon: Chiron Press.

PAyne, R. B. \& PAYNe, K. 1977. Social organization and mating success in local song populations of Village Indigobirds, Vidua chalybeata. Z. Tierpsychol. 45: 113-173.

Smark, G. A. F. 1973. The estimation of animal abundance and related parameters. London: Charles Griffin \& Co. Ltd.

ShePpB, W. 1975. Observations on the animal life of some Zambian hot springs. Ohio J. Sci. 75: $26-29$.

Sheppe, W. \& Osborne, T. 1971. Patterns of use of a flood plain by Zambian mammals. Ecol. Monogr. $41:$ 179-205.

Sinclair, A. R. E. 1978. Factors affecting the food supply and breeding season of resident birds and movements of Palearctic migrants in a tropical African savannah. Ibis $120: 480-497$.

SKRAD, D. M. 1975. Ecological studies of four estrildines in the central Transvaal. Ostrich Suppl. 11.

SNow, D. \& SNow, B. K. 1964. Breeding seasons and annual cycles of Trinidad landbirds. Zoologica 49: $1-40$.

WARD, P. 1971. The migration patterns of Quelea quelea in Africa. Ibis 113: 275-297.

Woodall, P. F. 1975. The life history of the Bronze Mannikin. Ostrich 46: 55-86.

The Museum of Zoology and Division of Biological Sciences, The University of Michigan, Ann Arbor, Michigan 48109, U.S.A. 